\title{
Pertanggungjawaban Pidana Partai Ks Yang Menerima Hasil Tindak Pidana Korupsi Berdasarkan Undang-Undang Nomor 8 Tahun 2010
}

\author{
Sonia Adina Anggono \\ Fakultas Hukum Universitas Airlangga \\ niadina14@gmail.com
}

\begin{abstract}
LHI is a member of the The House of Representatives and at the same time, President of The KS Party. LHI received IDR 1.300.000.000,- and 1 unit of Toyota FJ Cruiser worth IDR 1.100.000.000,- from MEL as the Director of PT. $I U$ in January 2013. The provision is given relating to the position of LHI as a member of The House of Representatives, LHI was asked to influence fellow members of The House of Representatives and $S$ as the Minister of Agriculture who is also a member of The KS Party. $S$ was expected to issue a letter of approval for the application of additional beef import quota proposed by PT. IU. 1 unit of Toyota FJ Cruiser was then donated by LHI to The KS Party. According to the criminal liability of corporation theory which is Identification Theory, the act of General Secretary and General Treasurer of The KS Party is identified as the act of The KS Party. It makes The KS Party criminally liable for receiving a donation from the proceed of crime and use it for its Safari Dakwah activity as part of its campaign in Sumatera.
\end{abstract}

Keywords : Corruption, Money Laundering, Criminal Liability of Corporation

\begin{abstract}
Abstrak
Tindak pidana pencucian uang berdasarkan Undang-Undang Nomor 8 Tahun 2010 diklasifikasikan menjadi tindak pidana pencucian uang aktif dan pasif. Pencucian uang pasif adalah perbuatan menerima atau menguasai atau menggunakan hasil tindak pidana. Pencucian uang pasif dapat dilakukan korporasi termasuk partai politik. LHI adalah anggota Dewan Perwakilan Rakyat dan sekaligus Presiden Partai KS. Pada bulan Januari 2013, LHI menerima uang sebesar Rp. 1.300.000.000,- dan 1 (satu) unit mobil Toyota FJ Cruiser seharga Rp 1.100.000.000,- dari MEL selaku Direktur Utama PT. IU. Pemberian tersebut diberikan berkaitan dengan jabatan LHI selaku anggota Dewan Perwakilan Rakyat, LHI diminta untuk mempengaruhi sesama anggota Dewan Perwakilan Rakyat dan mempengaruhi $S$ selaku Menteri Pertanian yang juga merupakan anggota Partai KS. S diharapkan menerbitkan surat rekomendasi persetujuan pemasukan atas permohonan penambahan kuota impor daging sapi yang diajukan oleh PT. IU. 1 (satu) unit mobil Toyota FJ Cruiser kemudian disumbangkan oleh LHI kepada Partai KS. Berdasarkan teori pertanggungjawaban pidana korporasi yaitu Teori Identifikasi, perbuatan Sekretaris Jenderal dan Bendahara Umum Partai KS sebagai pengurus yang menerima hasil tindak pidana korupsi diidentikkan menjadi perbuatan Partai KS sehingga Partai KS dapat dikenakan pertanggungjawaban pidana karena menerima sumbangan mobil hasil tindak
\end{abstract}


pidana dan menggunakannya untuk kegiatan Safari Dakwah dalam rangka kampanye di Sumatera.

\section{Kata Kunci: Korupsi, Pencucian Uang, Pertanggungjawaban Pidana Korporasi}

\section{Pendahuluan}

Tindak pidana korupsi semakin banyak terjadi dan menyita banyak perhatian dari masyarakat. Pelaku yang terjerat kasus korupsi di Indonesia didominasi oleh anggota Dewan Perwakilan Rakyat. Komisi Pemberantasan Korupsi dalam Laporan Tahunan Tahun 2012 menunjukkan data statistik tersangka atau terdakwa kasus tindak pidana korupsi berdasarkan tingkat jabatannya yang tertinggi adalah anggota Dewan Perwakilan Rakyat atau Dewan Perwakilan Rakyat Daerah yaitu berjumlah 16 (enam belas) orang dari total 50 (lima puluh) orang tersangka atau terdakwa kasus tindak pidana korupsi pada tahun tersebut (Laporan Tahunan KPK, 2012:73).

Para pelaku tindak pidana korupsi tidak serta merta menggunakan hasil yang diperoleh dari tindak pidana, melainkan berupaya untuk menyamarkan hasil yang diperoleh dari tindak pidana tersebut sehingga seakan-akan diperoleh dari hasil kegiatan yang sah. Kegiatan menyamarkan asalusul harta kekayaan yang berasal dari tindak pidana menyebabkan pelaku melakukan tindak pidana lanjutan (follow-up crime) yang dikenal sebagai tindak pidana pencucian uang. Pusat Pelaporan dan Analisis Transaksi Keuangan (PPATK) mengelompokkan tindak pidana pencucian uang berdasarkan Undang-Undang Nomor 8 Tahun 2010 sebagai berikut:

TPPU dapat dikelompokkan dalam 2 (dua) klasifikasi, yaitu TPPU aktif dan TPPU pasif. Secara garis besar, dasar pembedaan klasifikasi tersebut, penekanannya pada: (PPATK ELearning, 4)

A. TPPU aktif sebagaimana dirumuskan dalam Pasal 3 dan 4 UU TPPU, lebih menekankan pada pengenaan sanksi pidana bagi:

1) Pelaku pencucian uang sekaligus pelaku tindak pidana asal

2) Pelaku pencucian uang, yang mengetahui atau patut menduga bahwa harta kekayaan berasal dari hasil tindak pidana.

B. TPPU pasif sebagaimana dirumuskan dalam Pasal 5 UU 
TPPU lebih menekankan pada pengenaan sanksi pidana bagi :

1) Pelaku yang menikmati manfaat dari hasil kejahatan

2) Pelaku yang berpartisipasi menyembunyikan atau menyamarkan asal usul harta kekayaan.

Undang-Undang Nomor 8 Tahun 2010 Tentang Pencegahan dan Pemberantasan Tindak Pidana Pencucian Uang (selanjutnya disebut Undang-Undang Nomor 8 Tahun 2010) menjangkau baik pelaku tindak pidana pencucian uang aktif maupun pasif agar dapat dikenakan pertanggungjawaban pidana.

Tindak pidana pencucian uang pasif selain dapat dilakukan oleh orang perorangan juga dapat dilakukan oleh korporasi. Pada awalnya Kitab Undang-Undang Hukum Pidana hanya mengakui orang perorangan secara pribadi (naturlijk persoon) sebagai subyek hukum pidana dan berdasarkan asas universitas delinquere non potest, korporasi tidak dikenal sebagai subyek hukum pidana (Ali, 2008:48). Undang-Undang Nomor 8 Tahun 2010 pun mengakui korporasi sebagai subyek hukum pidana. Partai politik terklasifikasi ke dalam pengertian korporasi menurut Undang-Undang Nomor 8 Tahun 2010, sebagaimana yang dikemukakan oleh Darwan Prinst (2002:17):

Sedangkan korporasi dapat berbentuk badan hukum atau tidak. Adapun yang berbadan hukum, misalnya Perseroan Terbatas, Yayasan, Koperasi, atau Maskapai Andel Indonesia (IMA). Sedangkan korporasi yang tidak berbadan hukum, misalnya Firma, Commanditaire Vennootschap (CV), Usaha Dagang atau perkumpulan lainnya. Malahan, juga dapat menjangkau Partai Politik, Organisasi Massa, Lembaga Swadaya Masyarakat dan sebagainya.

LHI adalah anggota Dewan Perwakilan Rakyat Republik Indonesia Periode Tahun 2009-2014 dan sekaligus Presiden Partai KS. Pada bulan Januari 2013, LHI menerima uang sebesar Rp. 1.300.000.000 (satu miliar tiga ratus juta rupiah) dari keseluruhan uang yang dijanjikan sebesar Rp. 40.000.000.000 (empat puluh miliar rupiah), dan 1 (satu) unit mobil Toyota FJ Cruiser seharga Rp 1.100.000.000 (satu miliar seratus juta rupiah) dari MEL selaku 
Direktur Utama PT. IU. Pemberian tersebut diberikan berkaitan dengan jabatan LHI selaku anggota Dewan Perwakilan Rakyat, LHI diminta untuk mempengaruhi sesama anggota Dewan Perwakilan Rakyat dan S selaku Menteri Pertanian yang juga merupakan anggota Partai KS. S diharapkan menerbitkan surat rekomendasi persetujuan pemasukan atas permohonan penambahan kuota impor daging sapi sebanyak 10.000 (sepuluh ribu) ton untuk tahun 2013 yang diajukan oleh PT. IU dan anak perusahaannya. Berkaitan dengan tindak pidana korupsi yang dilakukan LHI, ada pihak lain yang menerima hasil tindak pidana tersebut. 1 (satu) unit mobil Toyota FJ Cruiser disumbangkan oleh LHI kepada Partai KS dan digunakan oleh Partai KS untuk kegiatan Safari Dakwah dalam rangka kampanye di Sumatera.

Berdasarkan uraian tersebut, maka permasalahan yang akan dibahas adalah pertanggungjawaban pidana Partai KS yang menerima hasil tindak pidana korupsi berdasarkan Undang-Undang Nomor 8 Tahun 2010 Tentang Pencegahan dan Pemberantasan Tindak Pidana Pencucian Uang.

\section{Metode Penelitian}

Untuk menjawab permasalahan yang telah dirumuskan dalam penulisan ini, maka metode penelitian yang digunakan berupa penelitian hukum yuridis normatif yang merupakan penelitian kepustakaan, yaitu penelitian terhadap bahan hukum primer dan bahan hukum sekunder yang terdiri dari peraturan perundang-undangan dan literatur-literatur terkait untuk memecahkan persoalan hukum atau permasalahan yang akan dibahas.

Pendekatan masalah yang digunakan dalam penulisan ini adalah Statute Approach dan Conceptual Approach. Statute Approach adalah pendekatan masalah yang dirumuskan dan dikaji berdasarkan pendekatan terhadap ketentuan peraturan perundangundangan, sedangkan Conceptual Approach adalah pendekatan masalah yang didasarkan pada literatur-literatur, karya ilmiah, pendapat para sarjana, atau doktrindoktrin ilmu hukum. Pendekatan 
masalah baik Statute Approach maupun Conceptual Approach yang dilakukan adalah terhadap hal-hal yang memiliki korelasi dengan masalah yang dibahas.

Bahan hukum yang digunakan dalam penulisan ini adalah bahan hukum primer yaitu berupa peraturan perundang-undangan yang berlaku, yaitu Undang-Undang Nomor 8 Tahun 2010 Tentang Pencegahan dan Pemberantasan Tindak Pidana Pencucian Uang, Undang-Undang Nomor 31 Tahun 1999 Tentang Pemberantasan Tindak Pidana Korupsi, Undang-Undang Nomor 20 Tahun 2001 Tentang Perubahan Atas Undang-Undang Nomor 31 Tahun 1999 Tentang Pemberantasan Tindak Pidana Korupsi, dan Undang-Undang Nomor 2 Tahun 2008 Tentang Partai Politik, serta Undang-Undang Nomor 2 Tahun 2011 Tentang Perubahan Atas Undang-Undang Nomor 2 Tahun 2008 Tentang Partai Politik, serta bahan hukum sekunder yang terdiri dari literatur-literatur, karya ilmiah, pendapat para sarjana, dan doktrin-doktrin ilmu hukum yang berkaitan dengan masalah yang dibahas.
Langkah penulisan yang menggunakan studi kepustakaan ini diawali dengan mengumpulkan bahan-bahan hukum yang memiliki korelasi dengan masalah yang dibahas, kemudian dilakukan klasifikasi terhadap bahan-bahan hukum yang terkait untuk disusun secara sistematis agar lebih mempermudah dalam membaca, mempelajari, dan melaksanakan studi pustaka.

Langkah pembahasan dilakukan dengan penalaran deduktif yaitu berawal dari pengetahuan yang bersifat umum yang diperoleh dari peraturan perundang-undangan dan literatur-literatur yang kemudian diterapkan pada permasalahan yang dibahas sehingga diperoleh jawaban dari permasalahan yang bersifat khusus.

\section{Hasil Dan Pembahasan}

Pertanggungjawaban Pidana Partai KS

Kedudukan tindak pidana pencucian uang sebagai follow up crime membuat tindak pidana ini selalu didahului oleh sebuah tindak pidana asal atau predicate offence. 
Berkaitan dengan tindak pidana pencucian uang pasif yang diduga dilakukan oleh Partai KS, tindak pidana asalnya adalah tindak pidana korupsi yang diduga dilakukan oleh LHI. Pelaku tindak pidana pencucian uang pasif adalah pelaku yang menerima atau menguasai harta kekayaan hasil tindak pidana yang dilakukan oleh pelaku tindak pidana asal. Perbuatan LHI yang adalah anggota Dewan Perwakilan Rakyat dan menerima uang, mobil serta janji dari MEL selaku Direktur Utama PT. IU diduga melanggar ketentuan Pasal 12 huruf a Undang-Undang Nomor 20 Tahun 2001 Tentang Perubahan Atas Undang-Undang Nomor 31 Tahun 1999 Tentang Pemberantasan Tindak Pidana Korupsi (selanjutnya disebut Undang-Undang Nomor 20 Tahun 2001).

Unsur pertama dari Pasal 12 huruf a Undang-Undang Nomor 20 Tahun 2001 adalah Pegawai Negeri atau Penyelenggara Negara. Penyelenggara negara ditentukan dalam Penjelasan Pasal 5 ayat (2) Undang-Undang Nomor 20 Tahun 2001, yaitu sebagaimana dimaksud dalam Pasal 2 Undang-Undang Nomor 28 Tahun 1999:

Penyelenggara Negara meliputi:

1) Pejabat Negara pada Lembaga Tertinggi Negara;

2) Pejabat Negara pada Lembaga Tinggi Negara;

3) Menteri;

4) Gubernur;

5) Hakim;

6) Pejabat negara yang lain sesuai dengan ketentuan peraturan perundang-undangan yang berlaku; dan

7) Pejabat lain yang memiliki fungsi strategis dalam kaitannya dengan penyelenggaraan negara sesuai dengan ketentuan peraturan perundang-undangan yang berlaku.

Berdasarkan ketentuan tersebut, LHI memenuhi unsur penyelenggara negara. LHI sebagai anggota Dewan Perwakilan Rakyat yang berasal dari Partai KS merupakan pejabat negara pada salah satu lembaga tinggi negara yaitu Dewan Perwakilan Rakyat.

Unsur kedua adalah menerima hadiah atau janji. Berkaitan dengan kasus tindak pidana korupsi yang dilakukan oleh LHI, LHI menerima uang sebesar Rp. 1.300.000.000 (satu miliar tiga ratus juta rupiah) dari keseluruhan uang yang dijanjikan sebesar Rp. 40.000.000.000 (empat 
puluh miliar rupiah), dan 1 (satu) unit mobil Toyota FJ Cruiser seharga Rp 1.100.000.000 (satu miliar seratus juta rupiah), serta janji berupa bantuan uang untuk penyelenggaraan Musyawarah Kerja Nasional Partai KS dari MEL selaku Direktur Utama PT. IU. Uang sebesar Rp. 1.300.000.000 (satu miliar tiga ratus juta rupiah) digunakan oleh LHI, sedangkan 1 (satu) unit mobil Toyota FJ Cruiser seharga Rp 1.100.000.000 (satu miliar seratus juta rupiah) disumbangkan oleh LHI kepada Partai KS.

Unsur ketiga adalah diketahui atau patut diduga bahwa hadiah atau janji tersebut diberikan. LHI patut menduga bahwa hadiah atau janji yang diberikan kepadanya adalah untuk menggerakkannya melakukan sesuatu dalam jabatannya karena LHI bersama AF beberapa kali bertemu dengan pihak pemberi yaitu MEL untuk membahas tentang kesediaan LHI yang merupakan anggota Dewan Perwakilan Rakyat untuk mempengaruhi sesama anggota Dewan Perwakilan Rakyat dan mempengaruhi $\mathrm{S}$ selaku Menteri
Pertanian yang juga merupakan anggota Partai KS.

Unsur keempat adalah untuk menggerakkan agar melakukan atau tidak melakukan sesuatu dalam jabatannya, yang bertentangan dengan kewajibannya. Uang, mobil, dan janji yang diberikan oleh MEL adalah agar LHI selaku anggota Dewan Perwakilan Rakyat dapat mempengaruhi sesama anggota Dewan Perwakilan Rakyat dan mempengaruhi $\mathrm{S}$ selaku Menteri Pertanian yang juga merupakan anggota Partai KS. S diharapkan menerbitkan surat rekomendasi persetujuan pemasukan atas permohonan penambahan kuota impor daging sapi sebanyak 10.000 (sepuluh ribu) ton untuk tahun 2013 yang diajukan oleh PT. IU dan anak perusahaannya. Hal yang dilakukan oleh LHI bertentangan dengan kewajibannya karena sebagai anggota Dewan Perwakilan Rakyat, LHI memiliki kewajiban sebagaimana diatur dalam ketentuan Pasal 5 angka 4 Undang-Undang Nomor 28 Tahun 1999 dan Pasal 208 ayat (3) Undang-Undang Nomor 27 Tahun 2009 tentang Majelis 
Permusyawaratan Rakyat, Dewan

Perwakilan Rakyat, Dewan

Perwakilan Daerah dan Dewan

Perwakilan Rakyat Daerah yang pada prinsipnya mengatur tentang anggota Dewan Perwakilan Rakyat dilarang melakukan korupsi, kolusi, dan nepotisme, serta dilarang menerima gratifikasi. Dengan terpenuhinya unsur-unsur pasal ini maka LHI terbukti melanggar ketentuan Pasal 12 huruf a Undang-Undang Nomor 20 Tahun 2001. Harta kekayaan berupa uang dan mobil yang diterima oleh LHI berasal dari tindak pidana korupsi sehingga memenuhi ketentuan Pasal 2 ayat (1) huruf a Undang-Undang Nomor 8 Tahun 2010 yang menentukan: "Hasil tindak pidana adalah Harta Kekayaan yang diperoleh dari tindak pidana korupsi."

Berkaitan dengan tindak pidana korupsi yang dilakukan LHI, salah satu harta kekayaan hasil tindak pidana korupsi yaitu 1 (satu) unit mobil Toyota FJ Cruiser seharga Rp 1.100.000.000 (satu miliar seratus juta rupiah) kemudian disumbangkan oleh LHI kepada Partai KS dan digunakan Partai KS untuk kegiatan
Safari Dakwah dalam rangka kampanye di Sumatera. Hal ini menyebabkan Partai KS yang tergolong sebagai korporasi diduga dapat dimintakan pertanggung jawaban pidana sebagai pelaku tindak pidana pencucian uang pasif.

Partai KS yang menerima hasil tindak pidana korupsi atau sebagai pelaku tindak pidana pencucian uang pasif diduga melanggar ketentuan Pasal 5 ayat (1) Undang-Undang Nomor 8 Tahun 2010. Unsur pertama dari Pasal 5 Undang-Undang Nomor 8 Tahun 2010 adalah setiap orang. Setiap orang yang dimaksud adalah sebagaimana ditentukan Pasal 1 angka 9 Undang-Undang Nomor 8 Tahun 2010, yaitu orang perseorang atau korporasi. Partai KS yang merupakan partai politik tergolong ke dalam korporasi menurut UndangUndang Nomor 8 Tahun 2010 karena Pasal 1 angka 10 Undang-Undang Nomor 8 Tahun 2010 menentukan: "Korporasi adalah kumpulan orang dan/atau kekayaan yang terorganisasi, baik merupakan badan hukum maupun bukan badan hukum." Tb. Irman S. (2006:11) berpendapat, kumpulan atau 
perkumpulan dapat digolongkan dalam arti luas dan arti sempit: "Perkumpulan dalam arti sempit, tidak bertujuan untuk mencari laba dan tidak menjalankan usaha atau non ekonomi yaitu; perkumpulan, perhimpunan, perikatan, persatuan, kesatuan serikat dan sebagainya."

Partai KS merupakan kumpulan orang yang terorganisir karena merupakan partai politik yang dibentuk oleh sekelompok warga negara Indonesia secara sukarela atas dasar kesamaan kehendak dan citacita, dan tidak bertujuan untuk mencari laba maupun menjalankan usaha karena partai politik dibentuk untuk memperjuangkan dan membela kepentingan politik anggota, masyarakat, bangsa, dan negara, serta memelihara keutuhan Negara Kesatuan Republik Indonesia berdasarkan Undang-Undang Dasar Negara Republik Indonesia Tahun 1945. Hal ini dipertegas oleh Miriam Budiardjo (2008:403-404) yang menyatakan: "Secara umum dapat dikatakan bahwa partai politik adalah suatu kelompok terorganisir yang anggota - anggotanya mempunyai orientasi, nilai-nilai, dan cita-cita yang sama." Oleh karena itu, partai politik yang dibentuk oleh sekelompok warga negara Indonesia dan merupakan suatu kelompok yang terorganisir menyebabkan Partai KS yang merupakan partai politik tergolong sebagai kumpulan orang yang terorganisasi.

Partai KS adalah badan hukum karena status badan hukum bagi partai politik di Indonesia adalah suatu keharusan, Pasal 3 ayat (1) Undang-Undang Nomor 2 Tahun 2011 mensyaratkan: "Partai Politik harus didaftarkan ke Kementerian untuk menjadi badan hukum." Status badan hukum bagi partai politik sangat penting karena kedudukan partai politik sebagai subyek hukum yang dapat melakukan hubungan hukum. Sebagai suatu badan hukum, partai politik memiliki harta kekayaan yang terpisah dari harta kekayaan para pendiri atau pengurusnya. Partai politik yang berbentuk organisasi, memiliki status sebagai badan hukum sehingga mempunyai harta kekayaan tersendiri yang terpisah dari para pendiri atau pengurusnya, serta menjadi subyek hukum dalam lalu lintas hubungan 
hukum membuat partai politik tergolong ke dalam pengertian korporasi menurut Undang-Undang Nomor 8 Tahun 2010.

Unsur kedua adalah menerima atau menguasai penempatan, pentransferan, pembayaran, hibah, sumbangan, penitipan, penukaran, atau menggunakan harta kekayaan. Mengenai unsur ini, menurut $\mathrm{R}$. Wiyono (2014:73) yang dimaksud dengan frasa menerima mengutip dari Kamus Besar Bahasa Indonesia adalah: "Mendapat atau menampung dan sebagainya sesuatu yang diberikan atau dikirimkan." Menurut Sutan Remy Sjahdeini (Wiyono, 2014:73), yang dimaksud dengan sumbangan adalah: "Harta kekayaan yang disumbangkan, termasuk apabila penerimaan sumbangan berupa harta kekayaan tersebut penerimaannya masih digantungkan pada syarat-syarat tertentu, atau apabila penerima harus memberikan imbalan berupa apapun." Yang dimaksud dengan harta kekayaan adalah sebagaimana ditentukan Pasal 1 angka 13 Undang-Undang Nomor 8 Tahun 2010: "Harta Kekayaan adalah semua benda bergerak atau benda tidak bergerak, baik yang berwujud maupun yang tidak berwujud, yang diperoleh baik secara langsung maupun tidak langsung." Berkaitan dengan kasus tindak pidana pecucian uang pasif yang diduga dilakukan oleh Partai KS yaitu menerima sumbangan 1 (satu) unit mobil Toyota FJ Cruiser seharga Rp 1.100.000.000 (satu miliar seratus juta rupiah) dari LHI dan kemudian digunakan untuk kegiatan Partai KS yaitu Safari Dakwah dalam rangka kampanye di Sumatera menyebabkan Partai KS memenuhi unsur menerima sumbangan dan menggunakan harta kekayaan. Partai KS memenuhi unsur menerima karena mendapat 1 (satu) unit mobil Toyota FJ Cruiser yang diberikan oleh LHI dan menggunakan untuk kegiatan Partai KS yaitu Safari Dakwah dalam rangka kampanye di Sumatera. Mobil tersebut disumbangkan oleh LHI karena mobil tersebut pada dasarnya adalah milik LHI dan disumbangkan kepada Partai KS. 1 (satu) unit mobil Toyota FJ Cruiser tersebut merupakan harta kekayaan karena harta kekayaan menurut ketentuan Pasal 1 angka 13 Undang- 
Undang Nomor 8 Tahun 2010 adalah semua benda baik bergerak maupun benda tidak bergerak, baik yang berwujud maupun yang tidak berwujud, yang diperoleh baik secara langsung maupun tidak langsung. Oleh karena itu, 1 (satu) unit mobil Toyota FJ Cruiser adalah benda bergerak yaitu benda yang menurut sifatnya bergerak karena dapat berpindah dan dipindahkan dari suatu tempat ke tempat lain dan berwujud.

Unsur ketiga adalah yang diketahuinya atau patut diduganya merupakan hasil tindak pidana sebagaimana dimaksud dalam Pasal 2 ayat (1). Berkaitan dengan kasus tindak pidana pencucian uang pasif yang diduga dilakukan oleh Partai KS, Partai KS menerima sumbangan harta kekayaan hasil tindak pidana dalam hal ini adalah hasil tindak pidana korupsi yang dilakukan oleh LHI karena perbuatan LHI melanggar ketentuan Pasal 12 huruf a Undang-Undang Nomor 20 Tahun 2001. Penjelasan Pasal 5 ayat (1) Undang-Undang Nomor 8 Tahun 2010 menentukan: "Yang dimaksud dengan patut "diduganya" adalah suatu kondisi yang memenuhi setidak-tidaknya pengetahuan, keinginan, atau tujuan pada saat terjadinya Transaksi yang diketahuinya yang mengisyaratkan adanya pelanggaran hukum.” Berdasarkan penjelasan Pemerintah dalam sidang Perkara Nomor 77/PUU-XII/2014 perihal pengujian Undang-Undang Nomor 8 Tahun 2010 terhadap Undang-Undang Dasar Negara Republik Indonesia Tahun 1945 terkait mengenai frasa patut diduga, frasa ini dikategorikan ke dalam bentuk kesalahan berupa kesengajaan sebagai suatu kemungkinan karena pelaku pada dasarnya mengetahui adanya kemungkinan yang akan terjadi akibat perbuatannya tetapi tetap melakukan perbuatan tersebut karena tidak percaya bahwa kemungkinan tersebut akan muncul.

Partai KS yang menerima sumbangan harta kekayaan berupa 1 (satu) unit mobil Toyota FJ Cruiser patut menduga bahwa harta kekayaan tersebut merupakan hasil tindak pidana. Partai KS dalam hal ini adalah Sekretaris Jenderal dan Bendahara Umum Partai KS sebagai pengurus Dewan Perwakilan Pusat, 
sebagaimana ditentukan dalam Pasal 22 ayat (3) Anggaran Rumah Tangga Partai KS yang menentukan: "Kepengurusan Dewan Pengurus Pusat sekurang-kurangnya terdiri atas Presiden, Sekretaris Jenderal, Bendahara Umum, Bidang, Badan, dan Departemen.” Sekretaris Jenderal dan Bendahara Umum Partai KS yang mewakili Partai KS menerima sumbangan patut menduga bahwa 1 (satu) unit mobil Toyota FJ Cruiser tersebut merupakan hasil tindak pidana karena disumbangkan oleh LHI yang merupakan Presiden Partai KS dan juga merupakan Dewan Perwakilan Rakyat. Perbuatan LHI yang menyumbangkan 1 (satu) unit mobil Toyota FJ Cruiser seharga Rp 1.100.000.000 (satu miliar seratus juta rupiah) tidak sesuai dengan profil LHI sebagai anggota Dewan Perwakilan Rakyat yang dalam Laporan Harta Kekayaan Penyelenggara Negara (LHKPN) menerangkan bahwa tidak memiliki sumber penghasilan lain kecuali yang berasal dari gaji dan tunjangan sebagai anggota Dewan Perwakilan Rakyat yaitu sebesar kurang lebih Rp
707.512 .800 (tujuh ratus tujuh juta lima ratus dua belas ribu delapan ratus rupiah) per tahun serta dukungan dana operasional sebesar Rp 70.000.000 (tujuh puluh juta rupiah) per bulan sebagai Presiden Partai KS. Berdasarkan Pasal 24 huruf k Anggaran Rumah Tangga Partai KS menentukan: "Tugas struktural Dewan Pengurus Pusat sebagai berikut: menerima dan mengelola hibah, dan sumbangan sukarela yang halal, sah, dan tidak mengikat." Sekretaris Jenderal dan Bendahara Umum Partai KS sesuai dengan ketentuan pasal dalam anggaran rumah tangga tersebut bertugas menerima dan mengelola sumbangan yang halal, sah, dan tidak mengikat sehingga dalam hal menerima sumbangan harus mengetahui asal usul setiap sumbangan yang diberikan kepada Partai KS.

Berkaitan dengan tahap-tahap proses pencucian uang yaitu placement, layering dan integration, perbuatan Partai KS yang menerima sumbangan harta kekayaan hasil tindak pidana korupsi berupa 1 (satu) unit mobil dari LHI tergolong ke 
dalam proses pencucian uang yaitu placement karena LHI menempatkan mobil yang merupakan hasil tindak pidana korupsi yang dilakukannya ke Partai KS dengan cara menyumbangkan mobil tersebut.

Partai KS telah terbukti melanggar ketentuan Pasal 5 ayat (1) Undang-Undang Nomor 8 Tahun 2010 sebagai pelaku tindak pidana pencucian uang pasif. Pasal 6 ayat (1) Undang-Undang Nomor 8 Tahun 2010 menentukan sistem pertanggungjawaban pidana korporasi: "Dalam hal tindak pidana Pencucian Uang sebagaimana dimaksud dalam Pasal 3, Pasal 4, dan Pasal 5 dilakukan oleh Korporasi, pidana dijatuhkan terhadap Korporasi dan/atau Personil Pengendali Korporasi." Pasal 1 angka 14 undang-undang tersebut menentukan yang dimaksud dengan Personil Pengendali Korporasi: "Personil Pengendali Korporasi adalah setiap orang yang memiliki kekuasaan atau wewenang sebagai penentu kebijakan Korporasi atau memiliki kewenangan untuk melakukan kebijakan Korporasi tersebut tanpa harus mendapat otorisasi dari atasannya." Oleh karena itu, berkaitan dengan tindak pidana pencucian uang pasif yang dilakukan oleh Partai KS dengan menerima sumbangan harta kekayaan hasil tindak pidana, maka sanksi pidana dapat dijatuhkan terhadap korporasi yaitu Partai KS dan/atau personil pengendali korporasi yaitu Sekretaris Jenderal dan Bendahara Umum Partai KS karena berdasarkan ketentuan Pasal 22 ayat (3) Anggaran Rumah Tangga Partai KS, pengurus Dewan Perwakilan Pusat Partai KS adalah Presiden, Sekretaris Jenderal, dan Bendahara Umum Partai KS. Sekretaris Jenderal dan Bendahara Umum Partai KS dikenakan pertanggungjawaban pidana terkait dengan kedudukan mereka untuk mewakili Partai KS menerima sumbangan harta kekayaan hasil tindak pidana dari LHI.

Suatu korporasi dapat dikenakan pidana apabila memenuhi ketentuan Pasal 6 Ayat (2) Undang-Undang Nomor 8 Tahun 2010 yang mensyaratkan: 
Pidana dijatuhkan terhadap Korporasi apabila tindak pidana Pencucian Uang:
a) dilakukan atau diperintahkan oleh Personil Pengendali Korporasi;
b) dilakukan dalam rangka pemenuhan maksud dan tujuan Korporasi;
c) dilakukan sesuai dengan tugas dan fungsi pelaku atau pemberi perintah; dan
d) dilakukan dengan maksud memberikan manfaat bagi Korporasi.

Berkaitan dengan ketentuan Pasal 6 ayat (2) huruf a, untuk dapat menjatuhkan pidana pada korporasi, tindak pidana pencucian uang harus dilakukan oleh Personil Pengendali Korporasi sendiri atau oleh orang lain dengan perintah dari Personil Pengendali Korporasi. Berdasarkan ketentuan pasal tersebut, UndangUndang Nomor 8 Tahun 2010 menganut teori pertanggungjawaban pidana korporasi yaitu identification theory karena menurut Barda Nawawi Arief (2010) mengutip pendapat Lord Morris dan Viscount Dilhorne yang dimaksud dengan identification theory adalah:

Identification Theory, atau disebut juga sebagai teori alter ego atau teori organ adalah suatu

\begin{abstract}
perbuatan/kesalahan "pejabat senior" ("senior officer") diidentifikasi sebagai perbuatan/kesalahan korporasi. Pengadilan Inggris yang menganut sempit teori ini menyatakan bahwa hanya perbuatan dari pejabat senior (otak korporasi) yang dapat dipertanggungjawabkan kepada korporasi, sedangkan Amerika Serikat yang menganut arti luas menyatakan tidak hanya pejabat senior/direktur tetapi juga agen dibawahnya. Sedangkan yang dimaksud dengan pejabat senior adalah orang yang tanggung jawabnya mewakili/melambangkan pelaksana dari "the directing mind and will of the company" atau seseorang yang dalam kenyataannya mengendalikan jalannya perusahaan (atau ia merupakan bagian dari para pengendali) dan ia tidak bertanggung jawab pada orang lain dalam perusahaan itu.
\end{abstract}

Undang-Undang Nomor 8 Tahun 2010 mensyaratkan korporasi dapat dikenakan pidana apabila tindak pidana pencucian uang dilakukan atau diperintahkan oleh setiap orang yang memiliki kekuasaan atau wewenang sebagai penentu kebijakan korporasi atau memiliki kewenangan untuk melakukan kebijakan korporasi tersebut tanpa harus mendapat 
otorisasi dari atasannya, sehingga dapat disebut sebagai the directing mind and will of the company. Berkaitan dengan kasus tindak pidana pencucian uang pasif yang diduga dilakukan oleh Partai KS, tindak pidana pencucian uang dilakukan oleh Personil Pengendali Korporasi atau the directing mind and will of the company karena dilakukan oleh Sekretaris Jenderal dan Bendahara Umum Partai KS yang menurut Anggaran Rumah Tangga Partai KS adalah pengurus Dewan Perwakilan Pusat yang memiliki kekuasaan atau wewenang sebagai penentu kebijakan Partai KS atau memiliki kewenangan untuk melakukan kebijakan Partai KS tanpa harus mendapat otorisasi dari atasannya.

Pasal 6 ayat (2) huruf b menentukan, untuk dapat menjatuhkan pidana pada korporasi maka tindak pidana pencucian uang harus dilakukan dalam rangka pemenuhan maksud dan tujuan korporasi. Pada kasus tindak pidana pencucian uang pasif yang diduga dilakukan oleh Partai KS, dalam Pasal 7 Anggaran Dasar Partai KS ditentukan tujuan Partai KS: "Tujuan Partai, yaitu terpenuhinya hak, kewajiban, dan tanggung jawab politik setiap Anggota sebagai warga negara dalam kehidupan berbangsa dan bernegara." Untuk mencapai tujuan tersebut, Partai KS menentukan sasaran-sasaran sebagaimana ditentukan dalam Pasal 2 Anggaran Rumah Tangga Partai KS: "Untuk mewujudkan tujuan Partai, dirumuskan sasaran-sasaran pencapaiannya sebagaimana diamanatkan dalam Falsafah Dasar Perjuangan Partai, Kebijakan Dasar Partai, dan Platform Kebijakan Pembangunan Partai, serta Rencana Strategis Partai." Pasal 3 huruf a Anggaran Rumah Tangga Partai KS menentukan: "Sasaran atau target Partai, antara lain: terselenggaranya pembinaan kepribadian insani atas dasar keseimbangan iman dan materi dalam upaya membentuk karakter bangsa dan peradaban manusia." Salah satu hasil tindak pidana korupsi yang dilakukan LHI adalah 1 (satu) unit mobil Toyota FJ Cruiser. Mobil tersebut kemudian disumbangkan oleh LHI kepada Partai KS dan digunakan Partai KS 
untuk kegiatan Safari Dakwah dalam rangka kampanye di Sumatera. Oleh karena itu, tindak pidana pencucian uang yang dilakukan oleh Partai KS adalah dalam rangka memenuhi tujuan Partai KS, yaitu melakukan Safari Dakwah dalam rangka kampanye Partai KS di Sumatera untuk menyelenggarakan pembinaan kepribadian insani atas dasar keseimbangan iman dalam upaya membentuk karakter bangsa dan peradaban manusia.

Pasal 6 Ayat (2) huruf c menentukan, untuk dapat menjatuhkan pidana pada korporasi maka tindak pidana pencucian uang harus dilakukan sesuai dengan tugas dan fungsi pelaku atau pemberi perintah. Pada kasus tindak pidana pencucian uang pasif yang diduga dilakukan oleh Partai KS, Pasal 24 huruf k Anggaran Rumah Tangga Partai KS menentukan: "Tugas struktural Dewan Pengurus Pusat sebagai berikut: menerima dan mengelola hibah, dan sumbangan sukarela yang halal, sah, dan tidak mengikat." Oleh karena itu, Sekretaris Jenderal dan Bendahara Umum Partai KS sebagai pengurus
Dewan Pengurus Pusat memiliki tugas salah satunya adalah untuk menerima dan mengelola sumbangan. 1 (satu) unit mobil Toyota FJ Cruiser adalah termasuk sumbangan sehingga penerimaan dan pengelolaannya adalah sesuai dengan tugas Sekretaris Jenderal dan Bendahara Umum Partai KS.

Pasal 6 ayat (2) huruf d menentukan, untuk dapat menjatuhkan pidana pada korporasi maka tindak pidana pencucian uang harus dilakukan dengan maksud memberikan manfaat bagi korporasi. Ukuran dengan maksud memberikan manfaat bagi korporasi adalah cukup dengan maksud awal untuk memberikan manfaat bagi korporasi tersebut. Pada kasus tindak pidana pencucian uang pasif yang diduga dilakukan oleh Partai KS, Partai KS mendapatkan manfaat karena dapat menggunakan 1 (satu) unit mobil Toyota FJ Cruiser untuk kegiatan Partai KS yaitu Safari Dakwah dalam rangka kampanye di Sumatera. Oleh karena ketentuan Pasal 6 ayat (2) Undang-Undang Nomor 8 Tahun 2010 telah terpenuhi, maka terhadap 
Partai KS dapat dimintakan pertanggungjawaban pidana.

\section{Simpulan}

Berdasarkan

pembahasan

tersebut, dapat disimpulkan bahwa

Partai KS dapat dimintakan pertanggungjawaban pidana berdasarkan Undang-Undang Nomor 8 Tahun 2010 karena subyek hukum pidana yang diakui dalam Pasal 1 angka 9 Undang-Undang Nomor 8 Tahun 2010 adalah orang perseorangan dan korporasi. Partai KS adalah partai politik yang tergolong dalam korporasi karena partai politik berbentuk sebagai organisasi yang terdiri dari kumpulan orang, memiliki status sebagai badan hukum sehingga mempunyai harta kekayaan tersendiri yang terpisah dari para pendiri atau pengurusnya. Partai KS menerima sumbangan 1 (satu) unit mobil Toyota FJ Cruiser seharga Rp 1.100.000.000 (satu miliar seratus juta rupiah) yang merupakan hasil tindak pidana korupsi yang dilakukan oleh LHI sehingga termasuk ke dalam ketentuan Pasal 2 Undang-Undang Nomor 8 Tahun 2010. Penerimaan sumbangan berupa mobil tersebut untuk dipergunakan dalam kegiatan Safari Dakwah Partai KS dalam rangka kampanye Partai KS di Sumatera memenuhi unsur-unsur Pasal 5 ayat (1) Undang-Undang Nomor 8 Tahun 2010 yaitu sebagai pelaku pencucian uang pasif. Partai KS memenuhi syarat-syarat penjatuhan sanksi pidana berdasarkan Pasal 6 ayat (2) UndangUndang Nomor 8 Tahun 2010. Berdasarkan Teori Identifikasi (identification theory), perbuatan pengurus yang memiliki kekuasaan atau wewenang sebagai penentu kebijakan Partai KS diidentikan dengan perbuatan Partai KS. Pengurus yang menerima sumbangan 1 (satu) unit mobil Toyota FJ Cruiser yang merupakan hasil tindak pidana korupsi adalah Sekretaris Jenderal dan Bendahara Umum Partai KS yang berdasarkan Anggaran Rumah Tangga Partai KS adalah pengurus yang memiliki kekuasaan atau wewenang sebagai penentu kebijakan partai sehingga tergolong dalam pengertian Personil Pengendali Korporasi. Partai KS dapat dijatuhkan sanksi pidana 
berdasarkan Pasal 6 ayat (1) UndangUndang Nomor 8 Tahun 2010 karena apabila perbuatan dilakukan oleh korporasi, maka pidana dijatuhkan terhadap korporasi dan/atau Personil Pengendali Korporasi. Perbuatan Sekretaris Jenderal dan Bendahara Umum Partai KS diidentikkan dengan perbuatan Partai KS sehingga pidana dijatuhkan terhadap Partai KS dan Sekretaris Jenderal dan Bendahara Umum Partai KS.

Oleh karena itu, seyogyanya partai politik yang terbukti menerima atau menguasai atau menggunakan hasil tindak pidana korupsi yang dilakukan oleh anggotanya dapat dikenakan sanksi pidana sebagai pelaku tindak pidana pencucian uang pasif karena partai politik tergolong ke dalam korporasi sehingga menjadi subyek hukum pidana dalam Undang-Undang Nomor 8 Tahun 2010, dan seyogyanya dengan diakuinya korporasi sebagai subyek hukum pidana, penegakan hukum terhadap pelaku pencucian uang pasif tidak hanya kepada orang perseorangan, tetapi juga kepada korporasi karena korporasi selain digunakan untuk memenuhi tujuan pelaku tindak pidana asal yaitu untuk menyamarkan asal-usul tindak pidana, tetapi korporasi juga mendapatkan keuntungan karena menerima atau menguasai atau menggunakan harta kekayaan hasil tindak pidana tersebut.

\section{Daftar Pustaka}

\section{Buku}

Ali, Mahrus, 2008, Kejahatan Korporasi, Yogyakarta : Arti Bumi Intaran.

Arief, Barda Nawawi, 2010, Kapita Selekta Hukum Pidana, Bandung : Citra Aditya Bakti.

Budiardjo, Miriam, 2008, Dasar-Dasar Ilmu Politik, Ed. Rev., Jakarta : Gramedia Pustaka Utama.

Prinst, Darwan, 2002, Pemberantasan Tindak Pidana Korupsi, Bandung : Citra Aditya Bakti

S., Tb. Irman, 2006, Hukum Pembuktian Pencucian Uang: Money Laundering, Bandung : MQS Publishing.

Wiyono, R., 2014, Pembahasan Undang-Undang Pencegahan dan Pemberantasan Tindak Pidana Pencucian Uang, Jakarta : Sinar Grafika.

\section{Laporan}

Laporan Tahunan
Pemberantasan Komisi
2012.

Website

PPATK E-Learning Anti Pencucian Uang dan Pencegahan 
Pendanaan Terorisme Bagian 4: Pengaturan Pencegahan dan Pemberantasan Pencucian Uang di Indonesia, [Diakses 15 Oktober 2014]

http://elearning.ppatk.go.id/plugin file.php/125/mod_page/content $/ 8 /$ Mod\%201\%20-

\%20Bag\%204\%20-

\%20Pengaturan\%20Pencegahan.p df. 